\title{
MOBILE AND CLOUD BASED SYSTEMS PROPOSAL FOR A CENTRALIZED MANAGEMENT OF EDUCATIONAL INSTITUTIONS
}

\author{
Leandro Medeiros de Almeida Machado \\ Faculdade de Tecnologia de São Paulo (FATEC), Brasil \\ E-mail: leandro.almachado@gmail.com
}

Felipe José Lopes Rita Universidade Federal de São Carlos, Brasil

E-mail: felipelopesrita@gmail.com

Carlos Henrique da Silva Santos Instituto Federal de Ciência e Tecnologia de São Paulo (IFSP), Brasil

E-mail: carlos.santos@ifsp.edu.br

Submission: 14/09/2016 Accept: 29/09/2016

\section{ABSTRACT}

The computational technological efforts towards a centralized data storage and processing have contributed to provide more sustainable solutions under the environmental, administrative and business perspectives. However, it is not yet worldwide adopted by public institutions, specially, in the Brazilian educational systems, where these technological models are still under constant discussions and development. In this sense, this work presents a brief survey about cloud and mobile integrated technologies and their possible contributions to support a centralized data management in educational systems, relating improvements in governance, data security, mobility, economic viability and environmental impact. Therefore, this work also present a list of already free and private technologies and their advantages and disadvantages in the Brazilian scenario. In this sense, the herein technological aspects considers the integration between cloud and mobile technologies as essential alternative to suppress the online requirements, which a limitation for a large number of public institutions that have problems to be effectively connected on the Internet. 
INDEPENDENT JOURNAL OF MANAGEMENT \& PRODUCTION (IJM\&P)

http://www.ijmp.jor.br

v. 8, n. 2, April - June 2017

ISSN: 2236-269X

DOI: $10.14807 /$ ijmp.v8i2.540

Keywords: Scholar Management; Cloud Computing; Economic Viability; Mobility; Data Connection; Governance

\section{INTRODUCTION}

The environmental protection aspects have widely been increased among worldwide people, concerning the problems intrinsically associated to the ratio demands and nature resources that already achieved alarming levels in pollution and their degradation caused by some organizations (BARBIERI; CAJAZEIRA, 2009). However, many of these organizations must offer their services and resources to attempt individual problems, which maximize the work-power and nature resources consume, consequently, they minimize their environmental protection and how it will impact future generations (FREIRE, 2007).

This scenario is not different in educational institutions, prevailing the immediate economic and demands ratios over the environmental impact, where there are a large financial demands in papers to print documents, printers and their consume items, computers and their maintenance, and electrical power to support these electronic equipments. These financial expenses have relatively been increased proportionally to the number of students in these educational institutions (PEREIRA; SANTOS, 2013).

However, today there are computational technologies that support the economy and efficiency of theses procedures, which also provides more efficiency, confidence, security, mobility and management tools by the data centralization in cloud computing and their worldwide data share or distribution with mobile devices (ARAÚJO; CAVALCANTE, 2015). Furthermore, the cloud computing adoption also contribute for the governance and comprehension about the laws and regulations, because they are, generally, developed under these assumptions.

Moreover, under the technological and environmental aspects in educational institutions, the centralized infrastructure promotes viable economic in the acquisition of computers (saving a computer server per institution), specialized work-power to attempt each institution in maintenance and trainings, data integrity and confidence, agility to response external auditors and the direct impact in power energy and paper consume. 
INDEPENDENT JOURNAL OF MANAGEMENT \& PRODUCTION (IJM\&P)

http://www.ijmp.jor.br

v. 8, n. 2, April - June 2017

ISSN: 2236-269X

DOI: 10.14807/ijmp.v8i2.540

However, this centralized infrastructure is complex to be mandatory in this continental country, by the unavailability or low access to the Internet, being the main disadvantage to be considered to design this solution (CRUZ; NERI, 2015).

In this scenario, this work presents in Sectionll some of the main Brazilian educational regulations and how the technologies are allowed to be introduced in private and public institutions. The Section III presents concepts and technologies available for cloud and mobile technologies to attempt educational institutions management, exemplifying with an App developed to communicate with a cloud system and to be execute in any mobile device to perform students frequency and assessments. This mobile integration is well justified by their offline work possibility allowed by a local database storage by the SQLite technology, which it can synchronize their data with this central cloud system by a Software as a Service (SaaS) (DIETMAR, 2012). Finally, the Section IV presents final remarks and the work in progress by these work team group.

\section{GOVERNANCE AND EDUCATION: BRAZILIAN REGULATIONS FOR TECHNOLOGIES SERVICES AND ACQUISITIONS}

The Brazilian Federal Constitution (BFC) was defined in 1988 and received many updates since then. It was created by National Constituent Assembly and its objective is to secure peoples individual and social rights, freedom, security, welfare, development, equality and justice as the main and supreme justice (Saraiva, 2016). It also designated the educational duties offers by the State and Family, and the individual obligations to live in a fraternity society. The BFC is taken as the mother law by the Brazilian institutions.

From this BFC Law, other federal institutions with vested rights, create their regulations, are those toward the education or for the use and purchase of services and technologies. For public institution they are the only path to attempt the public demands, as described in II.1. is presented the main educational regulations and II.2. the technological ones, since the management until the acquisitions and contract description.

\subsection{Educational Regulations: Governance and Management Aspects}

The Brazilian Educational basis is architecture regulated by the Law of Guidelines and Bases (LDB - Lei de Diretrizes e Bases), which was instituted in 
1996, and in its first article defines the educational scope and types of occurrence in society (BRASIL, 1996). Furthermore, this LDB also regulate the educational system and its levels and types, since from pre-school, permeating the elementary, highschool, technical and special offers, and how the professional and financial responsibilities shared by the Federal, State or Municipal hierarchy.

The Union Federation distributed the annual budget according to the previous Annual Budget Law (LOA - Lei Orçamentária Anual) and these governmental hierarchies are responsible to apply and monitor the financial resources, following the BFC and fiscal responsibility laws. In educational institutions, they also follows the LDB as a basic regulation to apply the minimal necessities, where an association to The National Educational Plan (PNE - Plano Nacional da Educação) is required in this instance (BRASIL, 2014).

The PNE regulates the educational priorities in a certain time interval, instead of some specific regulation with prior deadline specifications. These priorities basically attempts the BFC, under the article 214 , which main divided in six points, being (Free Translation of the $\mathrm{BFC}$ ):

a) illiteracy eradication;

b) universal school assistance;

c) improving the education quality;

d) work capacitation;

e) humanistic, scientific and technological advancement of the country.

f) the establishment of goals to apply public resources on education as a proportion of gross domestic product. (Included by Constitutional Amendment No. 59, 2009)

In the PNE, in its $2^{\text {nd }}$ article, the democratic management of public education is also associated to the principles of the human-rights, diversity and socialenvironmental sustainability (BRASIL, 2014).

These regulations are only a few necessary guidelines to offer and manage the educational institutions, since public and some of the private ones. In public institution, the employees also, basically, follows the Law N. 8.112, from December, $19^{\text {th }}, 1998$, which describe the juridical aspects of the civil public employees of 
INDEPENDENT JOURNAL OF MANAGEMENT \& PRODUCTION (IJM\&P)

http://www.ijmp.jor.br

v. 8, n. 2, April - June 2017

ISSN: 2236-269X

DOI: 10.14807/ijmp.v8i2.540

government agencies and foundations (BRASIL, 1990). This RJU point out the rights and duties of each public servant and establish that they are allowed to execute their activities only following the governmental regulations specific for each occupation and situation, including how the employee will interact with society and offers their services.

The Ministry of Education, for example, in December $29^{\text {th }}, 2008$, under the Law 11.892, institutionalize the Federal Professional, Science and Technology Education Network (RFEPCT - Rede Federal de Educação Profissional, Científica e Tecnológica), which composed by the Federal Institutes for Education, Science and Technology (IFs), by the Federal Technological Univeristy of Paraná (UTFPR), Federal Centre of Technological Education (CEFET) from Minas Gerais (CEFETMG) and Rio de Janeiro (CEFET-RJ) and Technical Schools associate to Federal Universities and the Colégio Pedro II. It is a network composed by almost 600 unities nationality distributed in the Brazilian Federation and employ close to 100.000 people, including administrative and professors that teach since the elementary until the doctorate graduate level (SETEC/MEC, 2016).

It is an interesting example of how complex could the management of a public national educational network and following the laws and other governmental regulations and their specific attributions for employees and their application in the educational offer. In this sense, tools are necessary to automatize these procedures and elucidate the steps necessary to conclude them. Herein, the recent computational are shown as alternative tools to attempt and support these demands and regulations. However, this technological adoption have also been regulated, and some of them are presented in the next section, under the governance perspectives.

\subsection{Governance and Technologies: Some Regulations and Instructions}

The Brazilian Federal Government has recently focused on the concious democratic digital inclusion, since the planning until the technologies use. These affirmations is partially based on the instruction and regulations to behave these processes, as the Normative Instruction Number 4 (NI-4/2014), from 11th November, 2014, whereby it regulates the processes to hire Information Technologies by the institutions members of System of Information Technology Resources (SISP - 
Sistema de Administração dos Recursos de Tecnologia da Informação) from the Federal Executive Branch (LORENI, 2014).

The IN-4/2014 regulates the players (people and institutions), documental, purchasing steps and ways to justify each technological item to be acquired, being a complex and bureaucratic procedure to establish some well defined planning specifications, as here simplified presented in Figure 1.

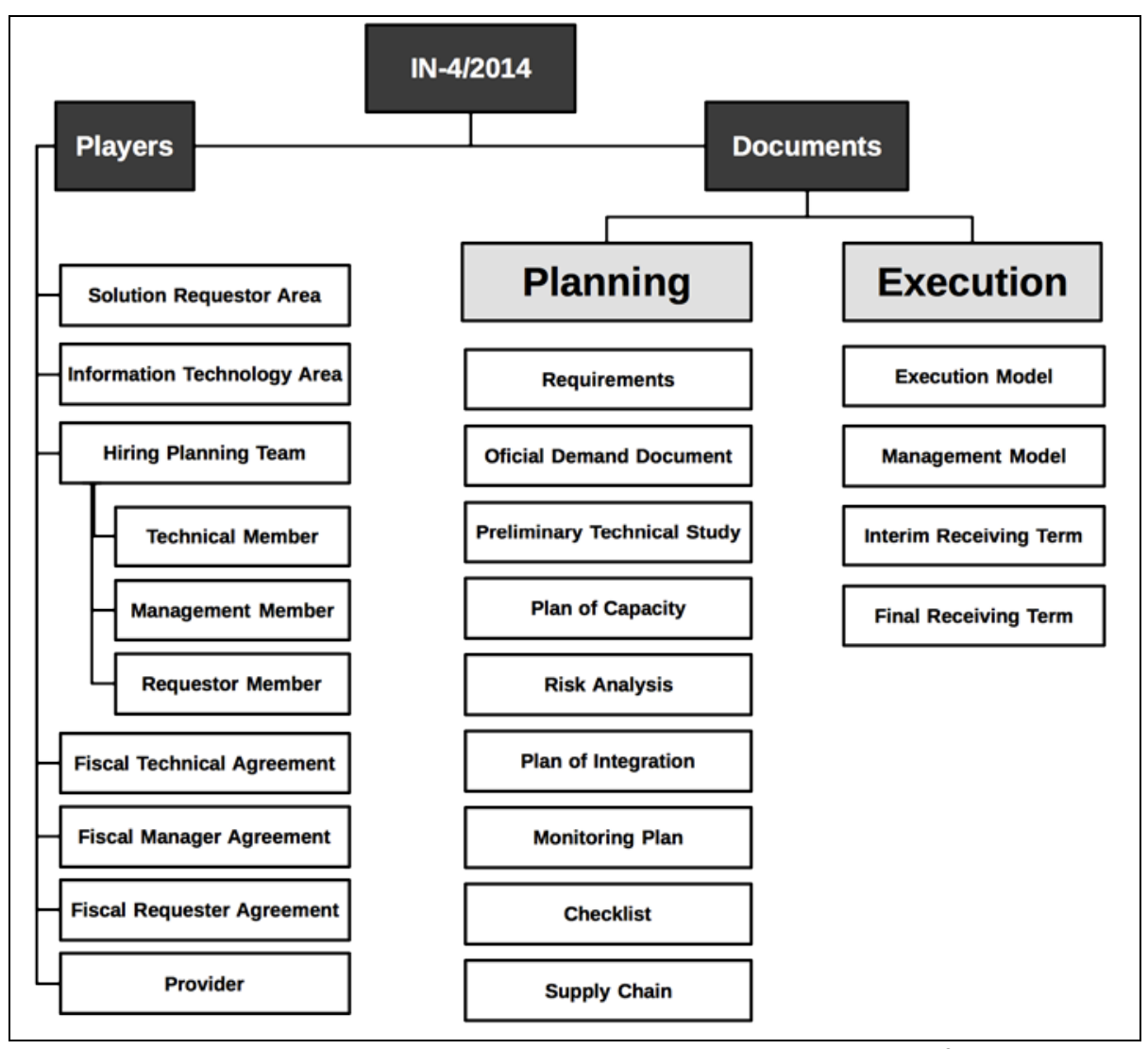

Figure 1: Documents and Players related in the IN-4 from 2014.

After the technologies acquisition, but focusing on the work team group management, the SISP published in 2013 a free and brief online tutorial to describe how to manage projects from SISP and support Information Technology Committees (ICTs) to manage their own Information Technology projects (SISP, 2013).

This document is based on the PMI (Project Management Institution) that specifies important recommendations internationally accepted and executed under their Foundational Standards described in the well known PMBOK Guide, where Executive, Project Portfolio, Project and Operational Management routines are grouped to simplify how the management activities are performed. 
INDEPENDENT JOURNAL OF MANAGEMENT \& PRODUCTION (IJM\&P)

http://www.ijmp.jor.br

v. 8, n. 2, April - June 2017

ISSN: 2236-269X

DOI: 10.14807/ijmp.v8i2.540

Furthermore, the SISP in association with Ministry of Planning, Budget and Management, has online free available template files to describe all artifact specified in the IN-4/2014 and following PMI/PMBok Governance recommendations procedures described in (SISP, 2013), which can be accesses in http://www.sisp.gov.br/mgpsisp/wiki/Artefatos.

This Wiki governmental site is also available instructions to analyze the current and continuity status of these projects, being an interesting tutorial to prime the It is an important document to evaluate the continuity of government projects or state plans regarding the use and acquisition of information technologies.

These documental references allows educational institutions to plan their software and hardware acquisition and development, planning their own systematic future, independent of the governmental conditions. However, they must plan their computational approaches firstly considering the financial costs (free software as much as possible), storing data in any national database to attempt the national sovereignty and specialized work-power to maintain these systems.

In this sense, this work proposed a cloud based system, where all management data from educational institution are available and some of these data also synchronized with mobile devices to provide flexibility and mobility for an multiplatform and national access, since considering the Brazilian distances (Figure 2).

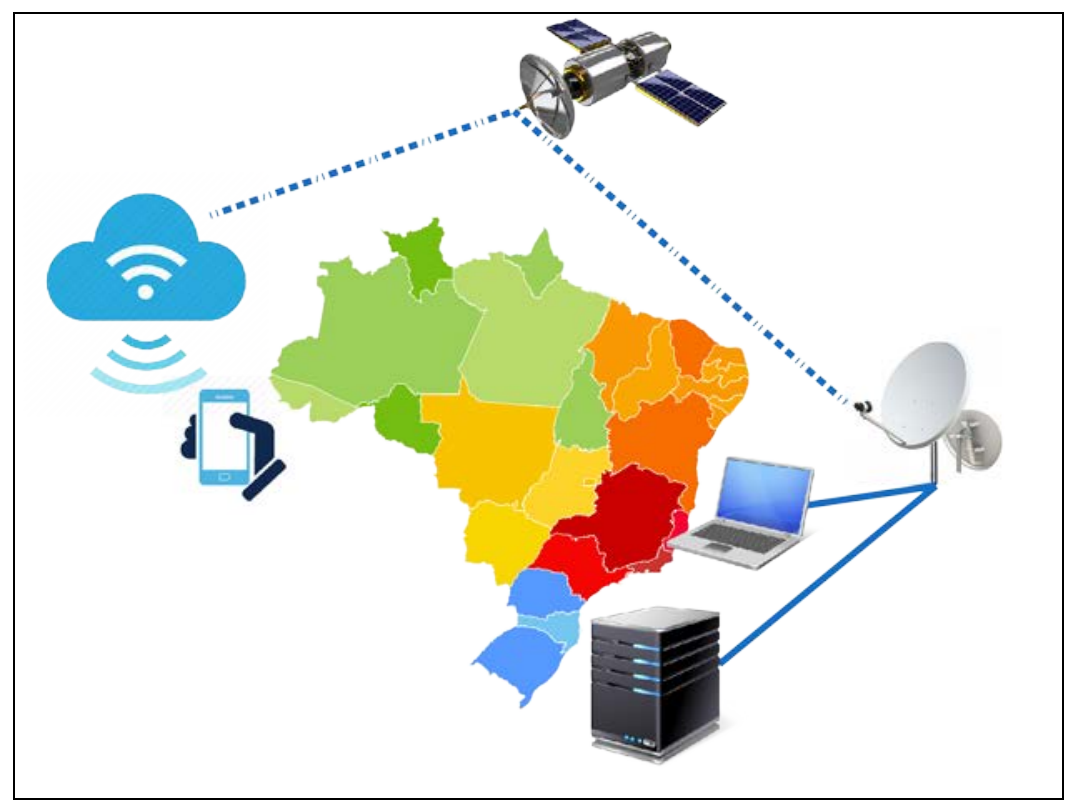

Figure 2.Brazilian cloud and mobile schematic for a national educational system. 


\section{PUBLIC AND PRIVATE TECHNOLOGIES ALREADY AVAILABLE TO USE AND DEVELOP APP AND CLOUD BASED TECHNOLOGIES}

The educational institutions procedures are different in almost of the cases, requiring some suitable computational routines to maximize its correct use. Henceforth, a simple UML User Case Diagram in Figure 3. is presented to represented the main/global educational relations here considered to list some technologies twofold already available for application and development of cloud/app based approaches, describe in subsections III.1 and III.2, respectively.

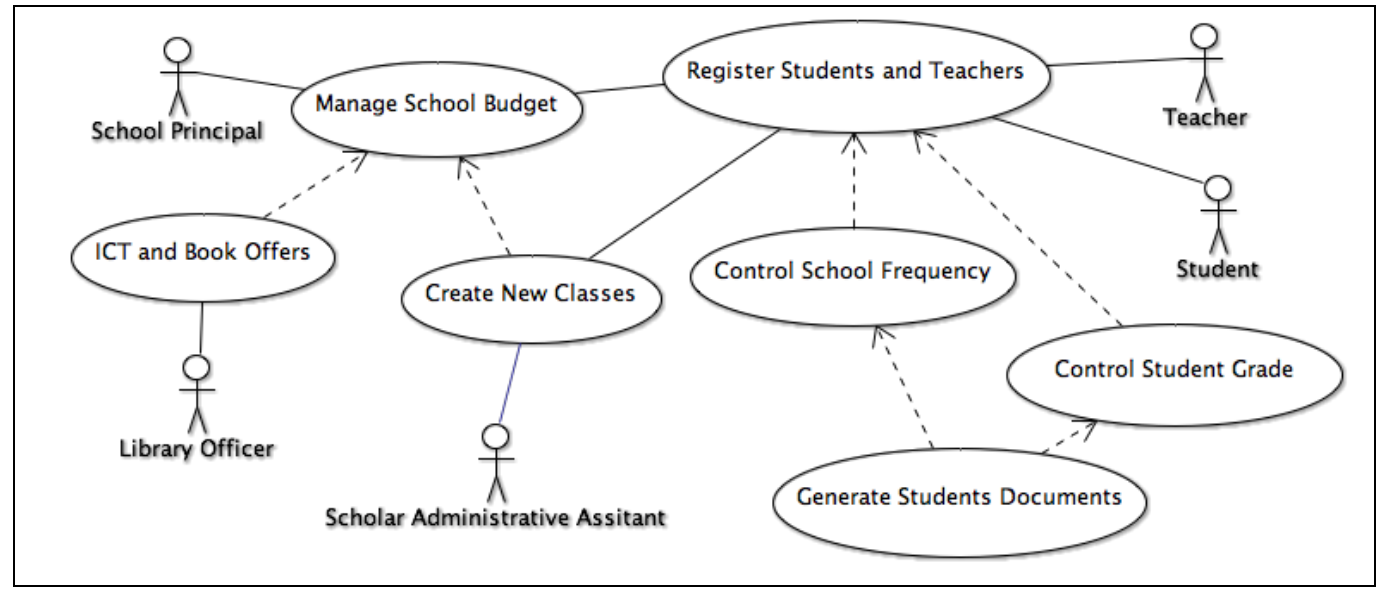

Figure 3.Simple User Case Diagram to Visualize Basic Services Relations.

\subsection{Technologies to Use: Downloading and Using}

The online stores and companies offers a wide range of mobile and cloud based software for educational environments. However, some software are here listed as a partial Web search and taking in account some of the services shown in Figure 3 , including free or private softwares to manage scholar environment beyond services offered by some Cloud Based system (SaaS) and mobile applications.

Therefore, the software Gennera, Ellucian, Sponte, Fekara and Renweb are below listed, taking in account their main computational approaches to save time, money and automatize some management proposed processes, scoring their relevant resources and pointing out their missing tools. It is important to emphasize that each software information is based on their software developer company website.

- Gennera: Operating in more than 750 institutions, in 25 Federative States and in the District Capital, also according to the official website, the Gennera software provides a fully modular based cloud solution that has as main 
purpose to support online professionalize the management of educational institutions. This system has a main module with initial resources and also provides functionality modules that can be added to the main module used in the management of the institution. Among all the available features present, they also highlighted their resources to support the communications between teachers, students and parents, aiding teachers' record and release notes, faults and events, as well as, official documents maintenance resources such as newsletters, enrollment and protocols, which can be viewed by parents, students and teachers as necessary. Another important aspect of the software is the possibility to integrated it with Enterprise Resource Planning (ERP) systems, as the SAP Business One. However, because it is a full web solution, the software does not have any application for mobile devices, being negative ineffectiveness in offline environments.

- Ellucian: it is a worldwide used software, including more than 2400 instutions and 18 millions of registered students. It is also modular system, being possile to acquire specific modules, as Gennera software. On the other hand, Ellucian offers a mobile based application to support the learning of students able to notify them of events or university warnings, teacher messages, and has integration with social networks with the purpose of maximizing iteration between the students. However, it is mainly maintained by the available college cloud database. Another important difference, is their financial modules that was created by themselves, instead of Gennera that allows the integration with some external ERP based module. As a negative information, this software focus only on institutions and higher education students, and has no application to mobile devices to aid teachers.

- Sponte: Unlike Ellucian, cited above, Sponte is a modular application that does not maintain a school level focus, with targeted modules from infant to graduate. Among the products offered by the software, one of the highlights is the ERP system for language schools in Brazil, according to the official website, it is used by more than 3,700 customers. In addition to the ERP service, among others, the system relies on the issuance of documents, frequency control and gradebook programming, proposing the computerization of institutional management described in this paper. 
Furhtermore, it has an application for students to perform academic appointments. However, similar to Ellucian, all access to the system carried out by the teacher and administrators is only performed via browser.

- Fekara: it is a software marketed by schemes, being a system for school management in a cloud computing that offers since from basic until advanced modules featured according to the acquisition of new schemes and it also has a free scheme aimed for small school. This free scheme has among its limitations, by the students register and how many people are allowed to used and their bandwidth connection. The Fekara has the advantage of a similar use of the Web application platform, enabling the use of both students and teachers. However, it has the downside of not having as many administrative tools that the previous ones, such as an ERP system robust present in all systems previously mentioned (copyright or integrated with a third party).

- Renweb: as around 300 featured and over 4000 user institutions. It is able to manage various relevant components in an educational institution, such as entrance exams, library, information about students and their parents, diaries class and documents generated by the institution.Negatively, as well as Fekara, does not have an integrated ERP system. However, the management of some resources is delegated to specific modules, such as the management of funds for the payment of employees, which is held in the module "Human Resources / CEU". Positively, among the previous software analyzed, the Renweb is the only one that has two mobile applications, being one facing the features that relate to the student, and another, made specifically to suit the features of the teacher. In addition, as was mentioned, possess a wide range of functionalities which can be aggregated.

Some summarized informations are presented in Table 1, associating App and Cloud based technologies approaches with actors that use them. 
Table 1. Main technologies and actors associations to automatize educational institutions management.

\begin{tabular}{c|r|r|r|r|r} 
& Gennera & Ellucian & Sponte & feKara & RenWeb \\
\hline Student App & $\mathrm{N}$ & $\mathrm{Y}$ & $\mathrm{Y}$ & $\mathrm{Y}$ & $\mathrm{Y}$ \\
\hline Teacher App & $\mathrm{N}$ & $\mathrm{N}$ & $\mathrm{N}$ & $\mathrm{Y}$ & $\mathrm{Y}$ \\
\hline Free Access & $\mathrm{N}$ & $\mathrm{N}$ & $\mathrm{N}$ & $\mathrm{Y}$ & $\mathrm{N}$ \\
\hline ERP System Integration & $\mathrm{Y}$ & $\mathrm{Y}$ & $\mathrm{Y}$ & $\mathrm{N}$ & $\mathrm{N}$ \\
\hline Target Institution & $\mathrm{N}$ & $\mathrm{Y}$ & $\mathrm{N}$ & $\mathrm{N}$ & $\mathrm{N}$ \\
\hline Frequency Control & $\mathrm{Y}$ & $\mathrm{Y}$ & $\mathrm{Y}$ & $\mathrm{Y}$ & $\mathrm{Y}$
\end{tabular}

\subsection{Technologies to Develop Cloud and App Based Software}

In order to satisfy every features previously mentioned and also attempt Brazilian regulations, for cloud/App based applications development for educational institutions request sophisticated computational resources as well as specialized professionals. It is necessary to support all native capabilities of mobile and operating systems devices, whether iOS or Android. Thus, the application must be able to work on multiple platforms (mobile, tablet, notebook, etc.), displaying unique behaviors when run on mobile devices, without any functionality lost. Withal, these computational solutions must have access the native capabilities of the device, such as access to offline database operations.

Thereby, different paths can be followed, considering: mobile and Web applications occurring in parallel and with different tools; or development of a unique hybrid application that supports different devices and media. Where each developer/user would mention strong and positive points of their toolboxes (WASSERMAN, 2010), where in the Website Stackshare (2016), listed three tools for hybrid application development in cloud computing and the strengths of the tool, according to users, as:

- Ionic: it enables rapid prototyping, by using AngularJS, which is a javascript framework maintained by Google widely known and used. It is a free and presented great designs that also attempts the MVC pattern by the integration of JS, HTML and CSS in the front-end and PHP as the main back-end language. In this sense, the Web based software interface reuse is easy. 
- PhoneGap: it is maintained by Adobe, under a free and user friendly developer tool that support many platforms, being a powerful framework that also integrate JS, HTML and CSS as front-end technologies;

- Xamarin: it is C\# programming language for mobile devices, also available in Microsoft .Net Platform with their native UI controls and performance. It is truly JS compiled code, which allows to share more than $90 \%$ of code over all platforms and attempt MVVM pattern.

\section{INITIAL EFFORTS TOWARDS AN INSTITUTIONAL EDUCATIONAL TECHNOLOGICAL CLOUD/MOBILE BASED SOLUTION - STUDENTS CLASS CONTROL MODULE}

An initial software version already presented in (MACHADO, et al; 2016) that attempt all governmental regulations and application requirements, including the integration of online and offline approaches.

Two different interconnected and synchronized system are proposed. At first, as the basic and core system, a cloud SaaS system was provided to attempt the usability and flexibility criteria to be useful in different devices, providing a responsive interface. The responsiveness may generally be defined as the suitability of the system interface to different devices such as, for example, desktop computers, smartphones and tablets (O'REILLY, 2007).

This feature is important for a system in cloud computing taking in account the usability flexibility, considering different computational display and devices. Moreover, the interface to meet the main browsers available and provide visual fast responses in low connection rate and clear interface features, the use of HTML5 languages is necessary, in association to CSS3 and JavaScript as shown in Figure 4, returning a lightweight data streams. Finally, the data storage architecture was chosen to easily integrate the Database Management System (DBMS) MySQL with PHP 5.5 language and the mobile database SQLite. 


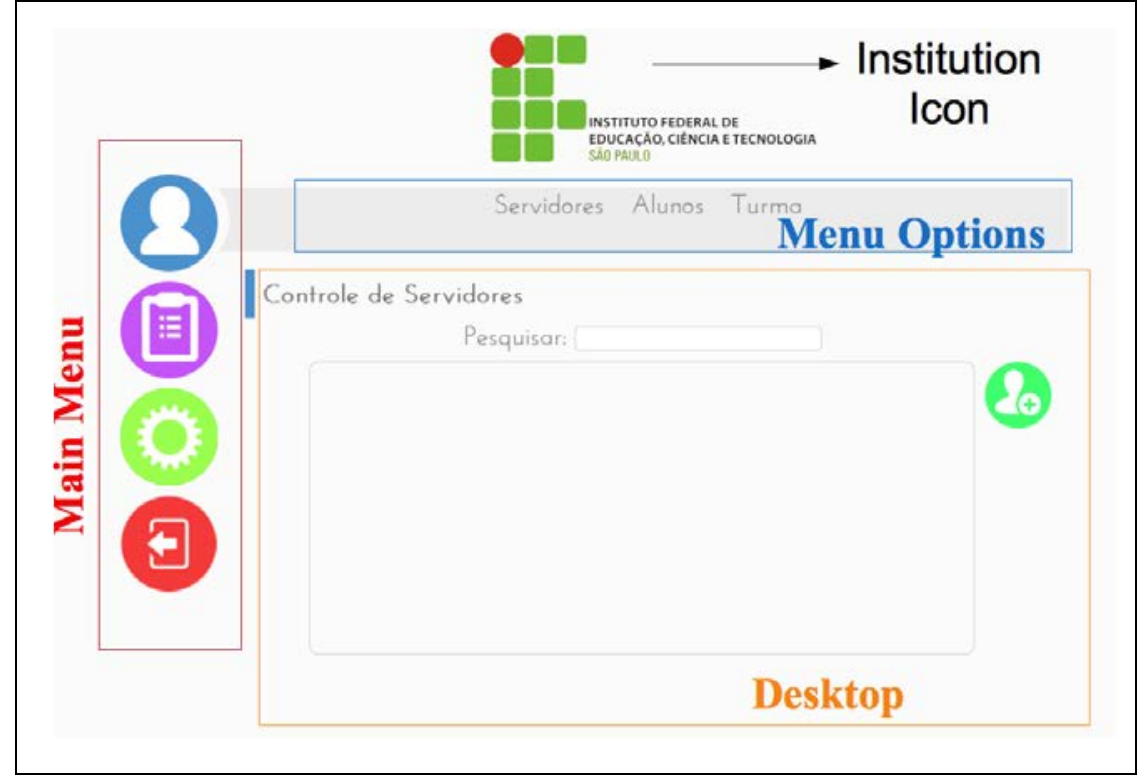

Figure 4. Main SaaS software interface.

On the mobile application (App) side, the PhoneGap framework was chosen as main technologic resource, being well justified by their PHP based language, simple developer interface, free online download as well as documented, and it provides simple object-data-connector with many databases, as shown in Figure 5.

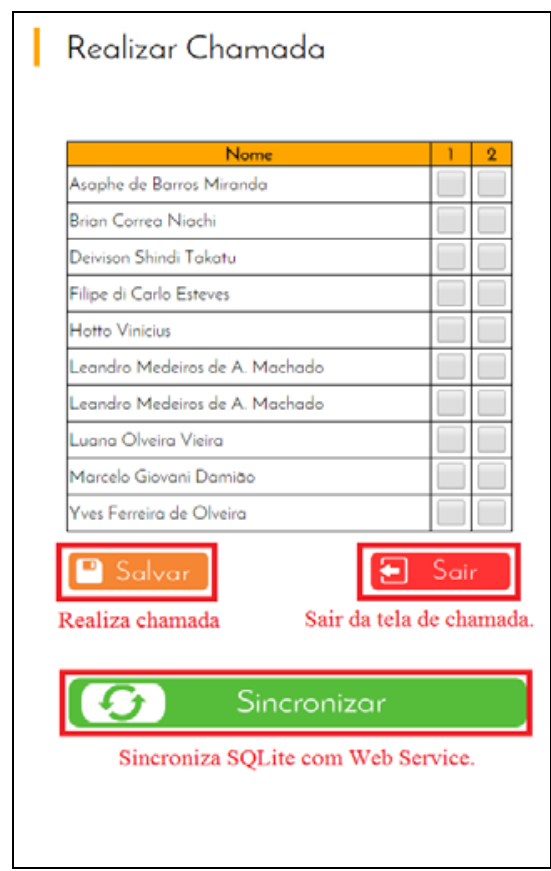

Figure 5. Main class frequency control app interface.

Besides the technological integrations possibilities, another important well stablished and validated resource is the device and screen acceptance, under some responsive techniques adopted from the Phonegap framework. In Figure 6 is showed multiple devices using the same App in different display resolution. 


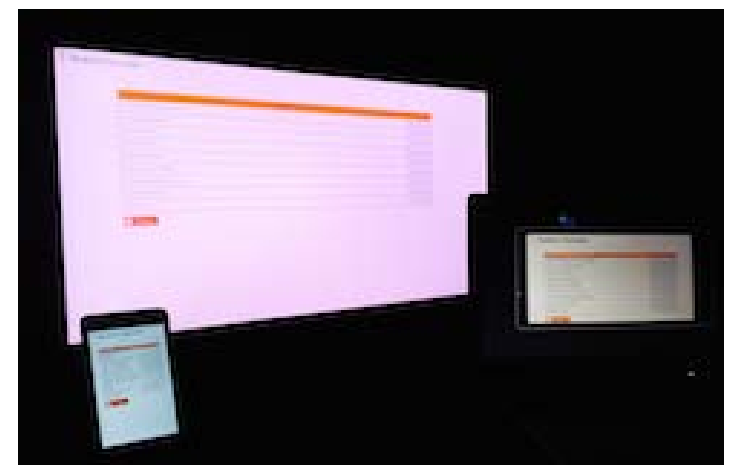

Figure 6. App multiple display interface example.

\section{CONCLUSIONS AND WORK IN PROGRESS}

This work is mainly a prospective review about Federal IT regulations in public institutions, focusing on the educational environments. In this sense, it also presents some online private or free system that partially attempt Brazilian educational institutions.

Therefore, a cloud based system to systematically centralize institutional data are proposed in association to a mobile application (App), as shown in Section IV with simple reference application to attempt all Federal regulations, which is now being extended to other functionalities, also considering technologies adopted by Federal Institutions, such the IFSP and their recent Web based software acquisitions.

This work team group is now working to insert novel management resources in this cloud-app based system, thinking to integrate some educational tools already adopted as learning objects in some classes. Thus, allow us to provide a suitable and free online platform for educational purposes.

\section{REFERENCES}

ARAUJO, B. D. L.; CAVALCANTE, V. M. R. M. (2015) Computação em Nuvens: Contribuição para a Sustentabilidade Econômica e Ecológica. Revista da Escola Regional de Informática v. 1, n. 1.

BARBIERI, J. C.; CAJAZEIRA, J. E. R. (2009) Avaliação do ciclo de vida do produto como instrumento de gestão da cadeia de suprimento-o caso do papel reciclado. Anais SIMPOI.

BRASIL, L. D. B. (1996) Lei 9394/96-Lei de Diretrizes e Bases da Educação Nacional. Disponível http://www. planalto. gov. br/ccivil_03/leis/19394. htm. Acesso em 20 de Julho de 2016. 
BRASIL, P. N. E. (2014) Lei 13.005/2014 - Lei Plano Nacional da Educação. disponível em: http://www.planalto.gov.br/ccivil_03/_Ato20112014/2014/Lei/L13005.htm, acessado em: 20 de Julho de 2016.

BRASIL, R. J. U. (1990) Lei 8.112/1990 - Lei Regime Jurídico dos Servidores úblicos Civis. disponível em:

http://www.planalto.gov.br/ccivil_03/leis/L8112cons.htm, acessado em: 20 de Julho de 2016.

CRUZ, A. G.; NERI, D. F. M. (2015) A inserção de tablets em escolas da rede pública estadual na cidade de Petrolina-PE: uma percepção dos educadores e educandos. Revista de Educação do Vale do São Francisco-REVASF, v. 4, n. 6, p. 06-26.

ARAUJO, B. D. L.; CAVALCANTE, V. M. R. M. (2015) Computação em Nuvens: Contribuição para a Sustentabilidade Econômica e Ecológica. Revista da Escola Regional de Informática v. 1, n. 1.

DIETMAR, K. (2012) Criar Aplicativos da Web Offline em Dispositivos Móveis com o HTML5, 1 out. 2012. Disponível em: <

http://www.ibm.com/developerworks/br/library/wa-offlineweb/>. Acesso em: 11 jan. 2016.

Freire, A. M. (2007) Educação para a Sustentabilidade: Implicações para o Currículo Escolar e para a Formação de Professores. Pesquisa em educação ambiental, v. 2 n. 1, p. 141-154.

LORENI F. F. (2014) Instrução Normativa 4, 11 de Setembro de 2014, Disponível em: <http://www.governoeletronico.gov.br/documentos-earquivos/IN\%204\%202014_compilada.pdf>, acessada em: 17/08/2016.

MACHADO, L. M. A.; LIMA, M. A.; RITA, F. J. L.; SANTOS, C. H. S. (2016) Software as a Service (SaaS) para a Gestão Escolar em uma Nuvem Computacional.

Sinergia (IFSP. Online).

O'REILLY, T. (2007) What is Web 2.0: Design patterns and business models for the next generation of software. Communications \& strategies, n. 1, p. 17.

PEREIRA, R. S.; SANTOS, D. A. (2013) Administrando a Escassez nas Instituições Federais de Ensino Superior.Estudos em Avaliação Educacional, v. 18, n. 36, p. 139-166.

SARAIVA, EDITORA. (2008) Vade Mecum. (Constituição Federal do Brasil). p. 776, São Paulo: Saraiva.

SECRETARIA DE EDUCAÇÃO PROFISSIONAL E TECNOLÓGICA (SETEC) (2016) Ministério da Educação (MEC), disponível em: http://redefederal.mec.gov.br/, acessado em: 20 de Julho de 2016.

SISTEMA DE ADMINISTRAÇÃO DE RECURSOS DE TECNOLOGIA DA INFORMAÇÃO (SISP) (2016) Metodologia de Gerenciamento de Portfólio de Projetos do SISP, disponível em:

<http://www.sisp.gov.br/mgpsisp/wiki/download/file/MGPP-SISP_Versao_1.0.pdf>, acessador em: 17/08/2016.

STACKSHARE, disponível em: http://stackshare.io/stackups/xamarin-vs-phonegapvs-ionic, acessado em: 29/08/2016. 
ISSN: 2236-269X

DOI: $10.14807 /$ ijmp.v8i2.540

WASSERMAN, A. I. (2010) Software engineering issues for mobile application development. Proceedings of the FSEISDP workshop on Future of software engineering research. ACM. 